\title{
Regeneration Pattern in Subtropical and Moist Temperate Forest Stands of Kashmir Himalayas
}

\author{
Hamayun Shaheen ${ }^{*}$, Sidra Nasar, Shamshad Aziz, Nosheen Mumtaz, Sadia Aziz \\ Department of Botany, University of Azad Jammu and Kashmir, Pakistan
}

Copyright $(2017$ by authors, all rights reserved. Authors agree that this article remains permanently open access under the terms of the Creative Commons Attribution License 4.0 International License

\begin{abstract}
Forest regeneration is a thrust area of vegetation studies having important implications and contributions for sustainable forest management. Regeneration pattern was investigated in western Himalayan moist temperate and subtropical forest sites in Bagh district, Azad Jammu and Kashmir. The anthropogenic pressure in terms of grazing and tree felling intensity was investigated. A very low regeneration values of 121 seedlings/ha was recorded for the whole area. Subtropical forests showed relatively higher regeneration value of 211 seedlings/ha. The seedling count for moist temperate forest sites was calculated as 119/ha. Stem/stump value of 1.62 was recorded for the forest stands showing immense tree felling intensity. Available grazing area per grazing unit was calculated as 0.16 ha/grazing unit whereas average herd size was 3 . Persistent grazing activity was recorded at all of the investigated forest sites. Multivariate statistical analyses revealed that anthropogenic disturbance stimuli were significantly correlated with retarded forest regeneration patterns. A gradual decline in tree felling and grazing intensity was observed with increasing altitude and distance from settlements; followed with an increase in seedling count.
\end{abstract}

Keywords Forest Regeneration, Seedling Count, Stem/Stump Value, Grazing Area, Himalayas

\section{Introduction}

Forest regeneration investigations are one of the thrust areas of vegetation studies having important implications and contributions for conservation, planning, decision making and sustainable forest management [1]. Forest structure and composition cannot be completely understood unless the regeneration patterns and factors governing them are not addressed [2]. Sufficient seedling population in the mature forest stands ensures successful regeneration as well as guarantees a secure future forest composition [3]. Forest regeneration is determined by a mosaic of different climax factors acting simultaneously including frequency and intensity of disturbances and microclimatic conditions of the site. Microclimate requirements vary from species to species depending upon their ecological niches [4]. The Himalayan conifers like Abies pindrow, Pinus wallichiana, Cedrus deodara and Picea smithiana prefer to grow in closed canopies with exposed mineral soils without thick litter cover $[5,6,7]$. Western Himalayan forests are severely degraded due to population rise and urbanization [8]. The disturbed forests with open canopies are characterized by abundant herbaceous under story due to higher light availability. Vigorous growth of sedges, bushes and herbs increases completion for the native tree seedlings by efficient resource utilization, severely retarding the regeneration patterns and delaying the succession $[9,10,11,12]$.

Himalayan communities exhibit traditional agro-pastoral life style with live stocks as an integral part of them. Livestock grazing in forests is a common practice as forest floors are the most important source of fodder round the year [13]. The composition of forest ground flora is significantly altered and modified by grazing practices. The areas with open livestock access exhibit noticeable decline in vegetation diversity, distribution patterns, and community structure and regeneration patterns [14]. The unsustainable livestock grazing practices are reported to have detrimental impacts on forest regeneration patterns in conifer forests due to browsing, trampling, increased soil erosion, soil compaction and reduced water infiltration $[15,16]$. Overgrazing can be caused either by too many animals or uncontrolled their grazing activity. With lesser available grazing area, grazers can switch to the woody vegetation along with grasses and shrubs [17]. Goats and sheep by nature prefer the leaves and twigs of trees as compared to grasses and herbs, eventually resulting in deterioration of tree vegetation. Goats are reported to consume the needle conifer leaves up to $220 \mathrm{~cm}$ by bending the trees down or climbing up, especially devastating for the seedlings. In some grazing-regeneration experiments the plant cover was found to be reduced to just $1 \%$, showing up to $90 \%$ basal cover destruction [18].

\section{Materials and Methods}

The research was carried out in moist temperate and 
subtropical forest stands of western Himalayas, in Bagh district, Azad Jammu \& Kashmir, Pakistan. Area lies at $73^{\circ} 75$ East longitudes and $33^{\circ} 90$ North latitudes; having subtropical to moist temperate vegetation with $54.58 \%$ area under forest cover [19]. The general elevation is between $1200 \mathrm{~m}$ in west to $3500 \mathrm{~m}$ in East. Average annual temperature is $16^{\circ} \mathrm{C}$, ranging from $2^{\circ} \mathrm{C}$ in January to $30^{\circ} \mathrm{C}$ in July. The annual precipitation is about $1500 \mathrm{~mm}$ [20].

The study was carried out during June to March 2015 starting with a preliminary survey in the 18 villages to investigate the socio-economic trends of communities as well as their dependence on natural resources and livestock. In each village 20 households were chosen involving people having different socio-economic backgrounds. Questionnaires were administrated and data about land holding, herd size, available grazing area and summer pasture migration practices was collected from inhabitants [21].

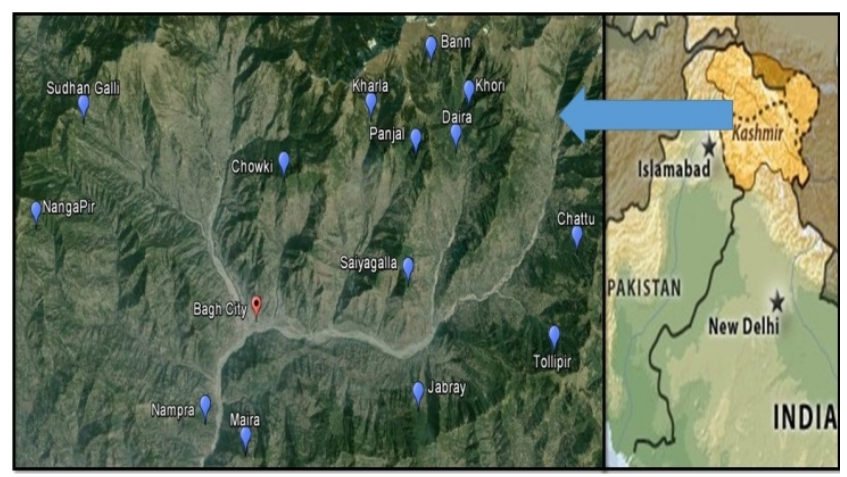

Figure 1. Location of the study area and satellite imagery of the investigated sites

Fifteen Sites including 12 moist temperate and 3 subtropical broad-leaved forests were selected for the study (Fig. 1). Sampling was stared at each site from the beginning of forest, at an average distance of 100 meters from the initial margins. Than onwards, quadrates were laid at every 250 meter distance, to record the gradual changes in vegetation dynamics and intensity of the anthropogenic and grazing pressure. The sampling was carried out until the vegetation climax community; showing minimum disturbance was reached [22]. 15 quadrates each were taken in blue pine, fir/spruce and oak zones. Co-ordinates including altitude, longitude and latitude of each studied site were recorded by using GPS. The regeneration of tree species was recorded by seedling count at each individual $900 \mathrm{~m}^{2}$ quadrate. The lumbering and tree felling intensity was recorded by counting the number of stumps and logs at each studied individual $900 \mathrm{~m}^{2}$ quadrate. Stump to tree value/ha were calculated using the recorded primary data. Grazing pressure in the studied sites was estimated by using visual indicators like browsed vegetation, cattle droppings, hoof marks and trampling trails for categorization of sites into low, moderate and highly grazed classes. Results were analyzed using multivariate techniques including Principal Component
Analyses (PCA) and Cluster Analyses (CA).

\section{Results}

An average seedling count of $124 /$ ha was calculated for the whole area forest stands with a lowest of 34/ha at Bann (moist temperate site) whereas maximum of 399/ha at Nampra (Subtropical site). Significant variations were observed in regeneration patterns within the studied individual sites as well as the vegetation zones. Pinus roxburghii-Quercus dilatata-Olea cuspidata forest zone prevailed in the lower altitudinal range of $1000-1400 \mathrm{~m}$. Three of the 15 forest sites lie in this zone including Nampra, Maira and Saiyagalla. An average seedling count of 211/ha was recorded in this zone. Abies pindrow-Pinus wallichiana forest zone prevails in upper altitudinal range of $1900-3000 \mathrm{~m}$. This is the most dominant moist temperate forest type, the identity of Western Himalayans. Twelve out of the 15 studied forest sites lay in this zone. An average seedling count of 122/ha was recorded from the area. Bann showed the least seedling count of 33/ha whereas Jabray showed the highest value of 224/ha (Table 1). The initial forest zone within $200 \mathrm{~m}$ from forest edge showed the highest seedling count at each site with an average of $145 / \mathrm{ha}$ ). An abrupt fall in seedling number was calculated at each site for the next $500 \mathrm{~m}$ with an average value of $88-100 / \mathrm{ha}$. This value than increased linearly till the middle of forest sites reaching maximum in the range of 140-155/ha; and at the end it once again decreased gradually till the forest ends to 110-120/ha, showing a parabolic curve. An average land holding of 0.89 ha with a herd size of 3 was determined in study area. Average grazing area of 0.16 ha per grazing unit was calculated for the study area. Moist temperate zone with Abies pindrow-Pinus wallichiana forests had an average grazing area of 0.109 ha per grazing unit. Broad leaved subtropical zone with Quercus dilatata-Pinus roxburghii-Olea cuspidata forest stands showed relatively higher grazing area of $0.22 \mathrm{ha}$ per grazing unit. An average stem/stump ratio of 1.62 was determined for the forest stands (Table 2). Nangapir forest site represented the most severe deforestation rates having a stem/stump value of 0.47 . Tollipir forest site showed the highest value of 2.31 . Significant variations were observed in tree logging practices along altitudinal gradient in all the forest sites. The initial quadrates within $1 \mathrm{~km}$ of forest edges showed the lowest stem/stump ratios in the range of $0.95-1.05$ (Fig 2). Especially the middle forest areas showed the least values, representing severe forest degradation by lumbering and logging. With increasing distance from the forest edges, value increased gradually. None of the 19 sites qualified for the low grazed class. 10 sites fell into moderately grazed class whereas 9 sites were included in heavily grazed class category. 
Table 1. Seedling count recorded along a distance gradient at the studies forest sites.

\begin{tabular}{|c|c|c|c|c|c|c|c|c|c|c|c|c|}
\hline \multirow{3}{*}{$\begin{array}{c}\text { Site } \\
\text { name } \downarrow\end{array}$} & \multirow{3}{*}{ Forest type } & \multicolumn{11}{|c|}{ Distance from settlements (meters) $\rightarrow \rightarrow \rightarrow$} \\
\hline & & 100 & 350 & 600 & 850 & 1100 & 1350 & 1600 & 1850 & 2100 & 2350 & $\mathrm{Av} / 900 \mathrm{~m}^{2}$ \\
\hline & & \multicolumn{11}{|c|}{ Number of seedlings/quadrate $\left(900 \mathrm{~m}^{2}\right) \downarrow \downarrow \downarrow$} \\
\hline Maira & \multirow{3}{*}{$\begin{array}{l}\text { Subtropical } \\
\text { broad leaved }\end{array}$} & 29 & 21 & 23 & 17 & 12 & 29 & 33 & 29 & 41 & 45 & 28 \\
\hline Nampra & & 41 & 32 & 17 & 23 & 12 & 12 & 3 & 7 & 12 & 14 & 18 \\
\hline Saiyagalla & & 0 & 2 & 13 & 11 & 22 & 9 & 16 & 11 & 13 & 9 & 11 \\
\hline Chatti & \multirow{13}{*}{$\begin{array}{c}\text { Moist } \\
\text { temperate } \\
\text { Coniferous }\end{array}$} & 2 & 3 & 4 & 7 & 7 & 5 & 6 & 6 & 7 & 5 & 6 \\
\hline Tollipir & & 15 & 3 & 9 & 13 & 11 & 21 & 6 & 9 & 5 & 7 & 10 \\
\hline Sudhan Gali & & 2 & 4 & 3 & 7 & 10 & 5 & 7 & 8 & 2 & 7 & 6 \\
\hline Chattu & & 0 & 4 & 3 & 4 & 13 & 9 & 23 & 31 & 25 & 21 & 14 \\
\hline Daira & & 6 & 4 & 7 & 6 & 19 & 9 & 5 & 7 & 13 & 10 & 9 \\
\hline Jabray & & 31 & 7 & 6 & 17 & 23 & 37 & 24 & 17 & 21 & 16 & 20 \\
\hline Panjal & & 5 & 3 & 5 & 7 & 13 & 5 & 3 & 3 & 7 & 2 & 6 \\
\hline Kharla & & 31 & 23 & 14 & 12 & 22 & 11 & 12 & 14 & 3 & 9 & 15 \\
\hline Chowki & & 12 & 9 & 12 & 9 & 10 & 9 & 5 & 7 & 2 & 1 & 8 \\
\hline Nangapir & & 12 & 9 & 11 & 10 & 19 & 13 & 7 & 11 & 7 & 4 & 11 \\
\hline Bann & & 2 & 0 & 0 & 1 & 7 & 3 & 5 & 1 & 7 & 2 & 3 \\
\hline Khori & & 2 & 1 & 5 & 0 & 13 & 7 & 1 & 5 & 4 & 3 & 4. \\
\hline $\mathrm{Av} / 900 \mathrm{~m}^{2}$ & & 13 & 8 & 9 & 10 & 14 & 12 & 10 & 11 & 11 & 10 & 11 \\
\hline \multicolumn{2}{|c|}{ Average/hectare } & 145 & 91 & 101 & 113 & 154 & 132 & 113 & 123 & 123 & 111 & 121 \\
\hline
\end{tabular}

Table 2. Stem/stump values recorded at the studied forest sites.

\begin{tabular}{|c|c|c|c|c|c|c|c|c|c|c|c|c|}
\hline \multirow{3}{*}{ Site name $\downarrow$} & \multirow{3}{*}{$\begin{array}{l}\text { Vegetation } \\
\text { type }\end{array}$} & \multicolumn{11}{|c|}{ Distance from settlements.(Meters) $\rightarrow \rightarrow$} \\
\hline & & 100 & 350 & 600 & 850 & 1100 & 1350 & 1600 & 1850 & 2100 & 2350 & Average \\
\hline & & \multicolumn{11}{|c|}{ Stem/stump values/ha $\downarrow \downarrow$} \\
\hline Maira & \multirow{3}{*}{$\begin{array}{c}\text { Subtropical } \\
\text { Broad } \\
\text { leaved }\end{array}$} & 0.79 & 1.24 & 0.69 & 0.44 & 2.13 & 3 & 1.52 & 1.59 & 2.04 & 2.45 & 1.6 \\
\hline Nampra & & 1.81 & 1.83 & 1.06 & 1.41 & 1.62 & 1.59 & 2.29 & 1.34 & 4 & 2.24 & 1.9 \\
\hline Saiyagalla & & 0.86 & 0.64 & 0.47 & 0.57 & 0.67 & 0.87 & 2.64 & 3.1 & 5.15 & 6.6 & 2.2 \\
\hline Chatti & \multirow{12}{*}{$\begin{array}{c}\text { Moist } \\
\text { temperate } \\
\text { Coniferous }\end{array}$} & 0.89 & 0.47 & 0.46 & 0.4 & 3 & 1.43 & 2 & 3 & 3.8 & 7 & 2.3 \\
\hline Tollipir & & 2.09 & 3.1 & 1.53 & 1.74 & 1.67 & 3.19 & 1.82 & 2.12 & 2.84 & 3 & 2.4 \\
\hline Sudhangalli & & 1.34 & 0.82 & 0.93 & 0.87 & 0.72 & 1.2 & 1 & 2.34 & 0.22 & 0.9 & 1.1 \\
\hline Chattu & & 0.25 & 0.48 & 0.38 & 0.48 & 0.64 & 1 & 3.5 & 4 & 3.63 & 4 & 1.9 \\
\hline Daira & & 0.17 & 0.5 & 0.75 & 1.2 & 0.38 & 0.48 & 0.62 & 1.25 & 0.67 & 0.47 & 0.7 \\
\hline Jabray & & 1.89 & 1.25 & 1.12 & 1.2 & 0.69 & 1.35 & 2.08 & 1.86 & 2 & 4.29 & 1.8 \\
\hline Panjal & & 0.06 & 0.19 & 0.34 & 0.54 & 0.57 & 0.62 & 1.67 & 1.72 & 3.67 & 3.25 & 1.3 \\
\hline Kharla & & 0.27 & 0.43 & 0.18 & 0.31 & 0.14 & 0.87 & 0.84 & 1.24 & 4.67 & 7 & 1.6 \\
\hline Chowki & & 0.86 & 0.69 & 0.75 & 1.23 & 0.42 & 1.3 & 0.45 & 2.17 & 1.43 & 3.5 & 1.3 \\
\hline Nangapir & & 0.18 & 0.43 & 0.29 & 0.69 & 0.55 & 0.43 & 0.34 & 0.77 & 0.19 & 0.78 & 0.5 \\
\hline Bann & & 2.17 & 1.43 & 5.5 & 2.34 & 0.36 & 1.15 & 1.58 & 1.14 & 1 & 3.6 & 2.1 \\
\hline Khori & & 2 & 2 & 2.5 & 2.17 & 0.81 & 1.47 & 3.75 & 0.89 & 3 & 2.38 & 2.1 \\
\hline \multicolumn{2}{|c|}{ Average } & 1.05 & 1.04 & 1.13 & 1.04 & 0.96 & 1.34 & 1.74 & 1.91 & 2.56 & 3.44 & 1.62 \\
\hline
\end{tabular}




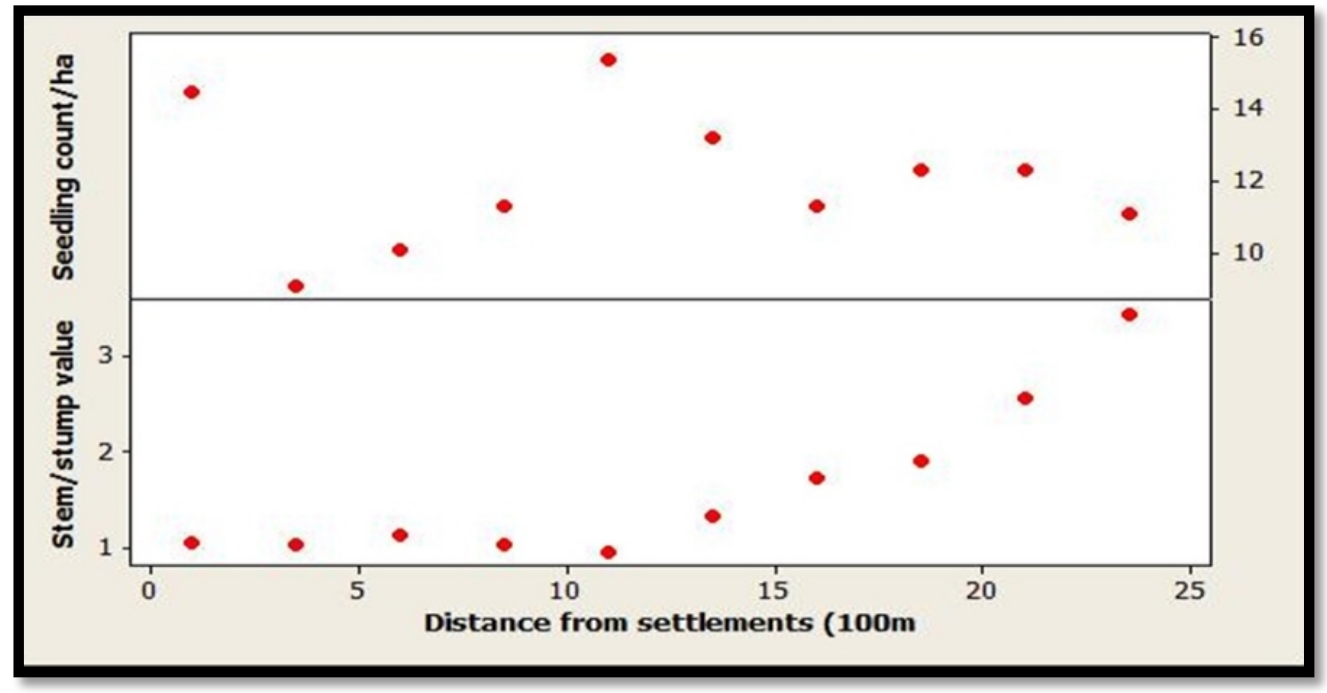

Figure 2. Matrix plot of Stem/stump value and seedlings/ha vs. distance from settlements/ha

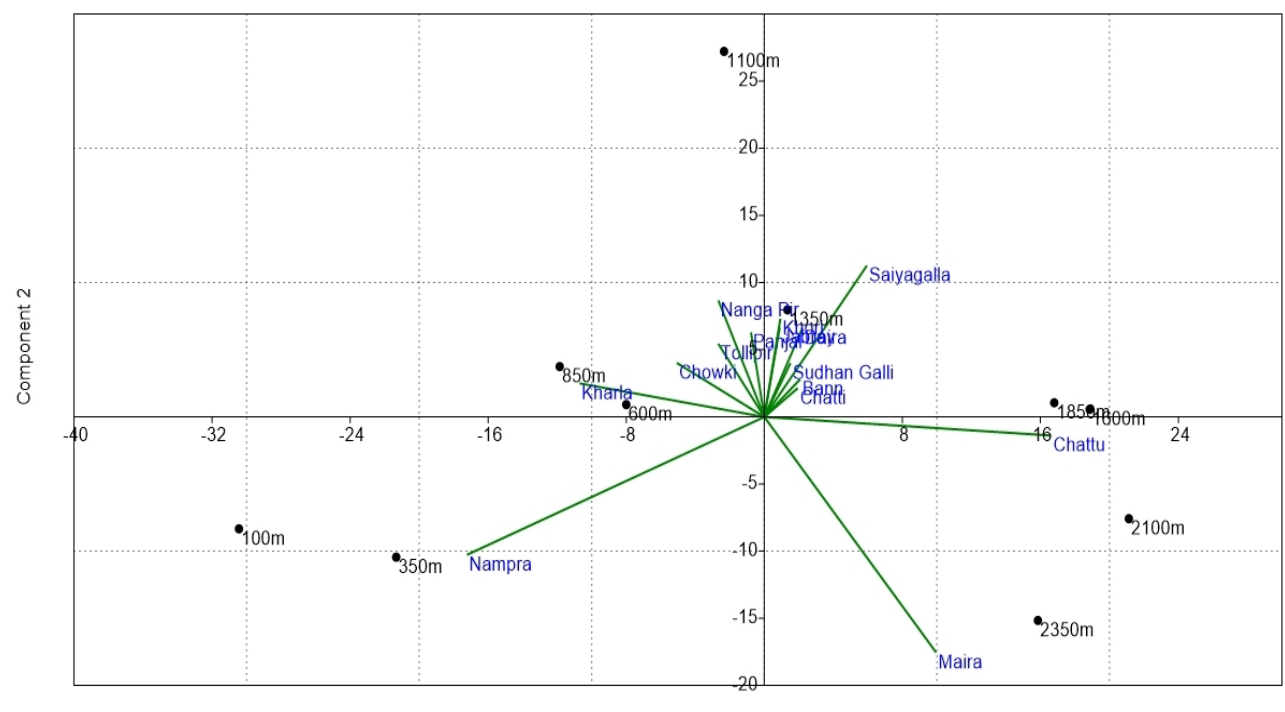

Component 1

Figure 3. Principal Component Analyses of forest sites along a distance gradient.

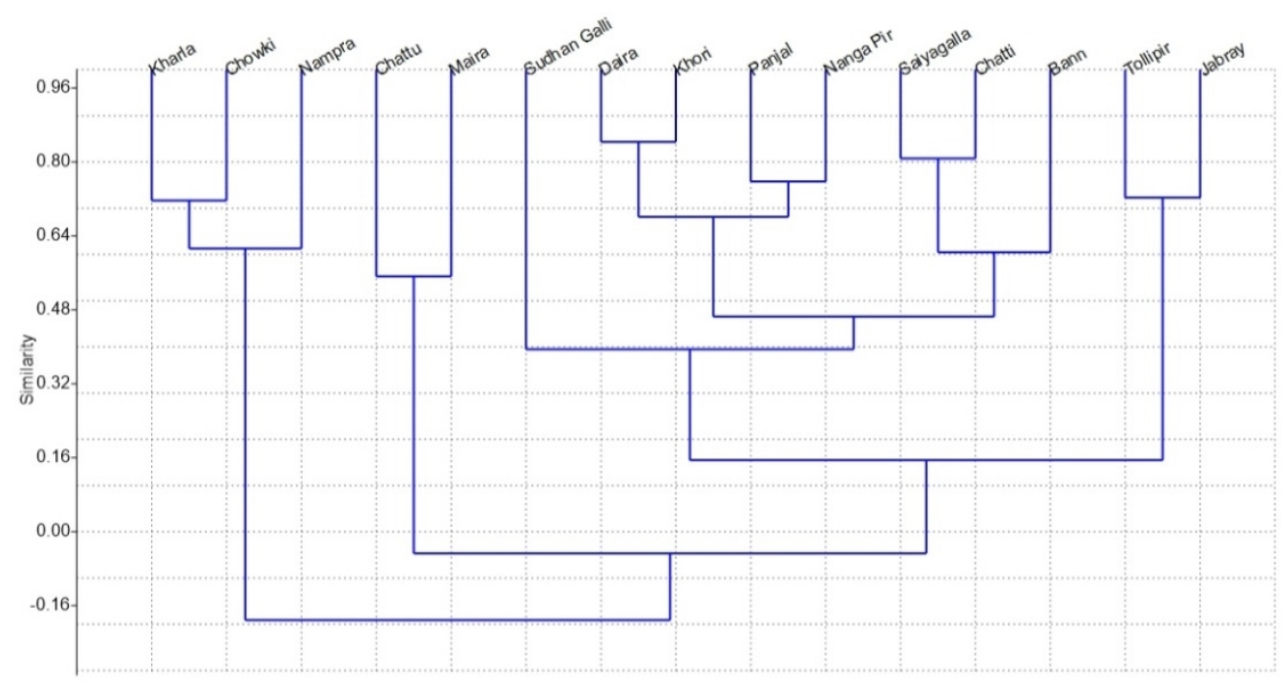

Figure 4. Cluster analyses dendrogram of forest sites based on Euclidean Distance. 
PCA explained $81 \%$ of the variance in the data along the $1^{\text {st }}$ two axes. Majority of the sites were clustered in the center on biplot characterized by low seedling counts (Fig. 3). Sites with highest regeneration at specific distance gradient points were clearly separated from the rest like Nampra, Maira and Saiya Galla. CA separated the sites based on Euclidean distance in 3 distinct clusters. The $1^{\text {st }}$ cluster at the extreme left of dendrogram comprised of the sites with highest regeneration values whereas the sites with moderate counts were clustered in the center in $2^{\text {nd }}$ group. The last cluster at extreme right consisted of sites with least seedling count (Fig. $4)$.

\section{Discussion}

The local forests showed extremely low tree regeneration rate of 124 seedlings/ha as compared to 1500-2300 seedlings/ha in Sikkim Himalayan subtropical forests [23]; 1750-3100 seedlings/ha in Himalayan forest of Bhutan [24]; 1977-3416 seedlings/ha in sub alpine and moist temperate forests of western Himalayas [25]. The factors responsible include absence of seedling care from grazing, trampling and harsh climatic conditions in most of the State Mountains; and immense lumbering and tree felling practices resulting in lower tree densities and lesser seed production [26]. Heavy uncontrolled grazing and trampling of approximately 400,000 local cattle along with 20,000 nomad grazers having more than 600,000 sheep and cattle is the primary reason of seedling depletion [27, 28]. Unfavorable and harsh climatic conditions of the area also contribute to the retarded forest regeneration.

Average grazing area was calculated due to its direct relationship with trends in forest regeneration. The lesser available grazing area results in shifting of grazing pressure to the surrounding forest lands having severe impacts on seedlings and shrubs. Average herd size in area was estimated to be 3 cattle/ household with an average grazing area of $0.16 \mathrm{ha}$, which is 21 times lesser than the ecologically permissible limit of $3.45 \mathrm{ha} /$ grazing unit/year for Himalayan moist temperate region [29]. This minimum value of 0.16 ha further decreased to 0.109 ha in Upper Bagh villages lying in the immediate vicinity of coniferous forests. Consequently the grazing pressure shifts to the surrounding forest reserves creating a massive stress on forest ground flora, shrubs and most important, the seedlings [30]. Normally with increase in degree of slope steepness the grazing intensity decreases as well [31]. But it was observed that in studied sites in spite of very steep slopes in the $60^{\circ}-75^{\circ}$ range, still very heavy grazing and browsing activity was observed. Grazing practices are one of very important determinants of forest vegetation distribution patterns and having most obvious impact on the floral biodiversity of an area [32]. This was evident from the observed heavy grazing activity in most of the sites. Sites having very steep slopes inappropriate for cattle grazing also showed heavy grazing activity mainly due to huge sheep and goat flocks in the area [33]. Sheep and goats are very specialized and active grazers which due to light weight and slim body structure, can easily graze in apparently inaccessible and difficult terrains. It is recommended by vegetation scientists that grazing practices in these fragile communities above 2000 meter should be very limited and controlled, and should be carried out in late summer after the full vegetation growth [34]. But in Kashmir forests, grazing activities start soon after the snow melts, in early growing season and continues until it again starts snowing [35]. The degraded vegetation in higher coniferous zone is further not allowed to repair itself by harsh climatic conditions and short growing period. It is reported that available grazing area in Kashmir decreased from 0.15 ha/animal in 1977 to 0.10 ha/animal in 1990's and it continues to decrease thereafter. Continuous and uncontrolled grazing also leads to suppressed growth of palatable grass species in pastures resulting in dominance of unwanted weeds and shrubs [36]; spread and of alien invasive species [37, 08]; replacement of perennial, palatable grasses by less nutritious unwanted weeds [38].

The subtropical broadleaved forests showed higher regeneration rate of 211/ha than 122/ha for moist temperate coniferous zone. This can be attributed to high regeneration capability of Quercus, Olea and Punica stumps as well as a longer and favorable growing season in lower zone [39]. An increasing regeneration trend was observed from forest margins towards center, which is significantly correlated with the decreasing grazing intensity away from settlements [40]. Highest seedling concentrations (130-150/ha) were recorded in middle of forest stands as compared to the lower and upper forest margins (80-110/ha) because of maximum canopy coverage and lesser grazing. Upper forest margins showed poor seedling count due to harsh climatic conditions with increasing altitudes. The very initial forest margins showed higher seedling counts at some places, due to some of departmental plantation schemes [41].

\subsection{Reforestation-Deforestation Equation}

The reforestation-deforestation equation in Kashmir state seems to be highly unbalanced and inclined towards deforestation. State forests are facing a reported annual loss of 15,000 ha due to tree felling, theft and illicit extractions and encroachments [22, 42]. The department claims to maintain an annual reforestation rate of 10000 ha. But due to regular forest exploitation by disturbing stimuli, harsh climatic conditions, absence of seedling care, experts state that the success rate of plantation cannot be more than $50 \%$, limiting it to $>5,000$ ha $[43,31]$. An annual 10,000 ha forest loss is revealed on comparing 5,000 ha reforestation with 15,000 ha deforestation. Successful regeneration requires both seedlings' establishment as well as secure survival controlled by microclimate of the site and anthropogenic stimuli. Even high initial seedling densities cannot guarantee successful regeneration in the areas with higher disturbance 
level like grazing and tree felling. Careful estimates reveal that if the current harvesting scenario goes on unchecked, the state forests will completely disappear by 2050 [44].

\section{Conclusions}

In the current scenario, moist temperate conifers with extremely low regeneration rates are expected to decline further in the future which can lead to the local extinction of these vital species in the area. High initial seedling densities cannot guarantee successful regeneration in the areas with higher disturbance. In these circumstances present reforestation rate does not seems sufficient to support the dying forests of state. Immediate planning and implementation of regeneration schemes is the need of hour to save the future of rapidly depleting forests of Kashmir Himalayas.

\section{REFERENCES}

[1] Bhuyan, P., M. Khan, and R. Tripathi. 2003. Tree diversity and population structure in undisturbed and human-impacted stands of tropical wet evergreen forest in Arunachal Pradesh, Eastern Himalayas India. Biodiversity \& Conservation 12 (8):1753-1773.

[2] Wangda, P. 2003. Forest Zonation along the complex altitudinal gradients in a dry valley of Punatsang-chu, Bhutan, Master's Thesis, The University of Tokyo, Japan, Tokyo.

[3] Saxena, A., and J. Singh. 1984. Tree population structure of certain Himalayan forest associations and implications concerning their future composition. Vegetatio 58 (2):61-69.

[4] Royo, A. A., and W. P. Carson. 2006. On the formation of dense understory layers in forests worldwide: consequences and implications for forest dynamics, biodiversity, and succession. Canadian Journal of Forest Research 36 (6):1345-1362.

[5] Knapp, A. K., and W. K. Smith. 1982. Factors influencing understory seedling establishment of Engelmann spruce (Picea engelmannii) and subalpine fir (Abies lasiocarpa) in southeast Wyoming. Canadian Journal of Botany 60 (12):2753-2761.

[6] Gratzer, G., P. Chhetri, A. Bürgi, and F. Godi. 2001. Regeneration of Picea spinulosa 10 years after a bark beetle outbreak. RNR-RC Jakar Annual Report.

[7] Zobel, D. B., and J. A. Antos. 1991. Growth and development of natural seedlings of Abies and Tsuga in old-growth forest. The Journal of Ecology: 985-998.

[8] Gupta, R. 1978. Impact of human influences on the vegetation of the Western Himalaya. Vegetatio 37 (2):111-118.

[9] Greenway, K. J., and V. J. Lieffers. 1997. A boreal forest grass with an open meadow photosynthetic strategy. Canadian journal of botany 75 (4):562-567.

[10] Coates, K., W. Emmingham, and S. Radosevich. 1991. Conifer-seedling success and microclimate at different levels of herb and shrub cover in a Rhododendron-Vaccinium-Menziesia community of south central British Columbia. Canadian Journal of Forest Research 21 (6):858-866.

[11] Berkowitz, A. R., C. D. Canham, and V. R. Kelly. 1995. Competition vs. facilitation of tree seedling growth and survival in early successional communities. Ecology: 1156-1168.

[12] Schnitzer, S. A., J. W. Dalling, and W. P. Carson. 2000. The impact of lianas on tree regeneration in tropical forest canopy gaps: evidence for an alternative pathway of gap - phase regeneration. Journal of Ecology 88 (4):655-666.

[13] Rosset, J. 1999. Temperate conifer forests of Bhutan. RNR-RC, Jakar, Special Publication (3).

[14] Kremen, C. 2005. Managing ecosystem services: what do we need to know about their ecology? Ecology letters 8 (5):468-479.

[15] Gill, R., and V. Beardall. 2001. The impact of deer on woodlands: the effects of browsing and seed dispersal on vegetation structure and composition. Forestry 74 (3):209-218.

[16] Irwin, L. L., J. G. Cook, R. A. Riggs, and J. M. Skovlin. 1994. Effects of long-term use by big game and livestock in the Blue Mountains forest ecosystems.

[17] Gordon, I., and A. Illius. 1992. Foraging strategy: from monoculture to mosaic. Progress in sheep and goat research: 153-177.

[18] Child, R., E. Byington, and H. Hansen. 1985. Goats in the mixed hardwoods of the southeastern United States.

[19] GoAJK. 2014. AJK at a glance: Official website of Planning and Development Department, Government of Azad Jammu \& Kashmir.

[20] Pak-Met. 2012. The Normal of Climatic Data of Azad Jammu \& Kashmir: Pakistan Meteorological Department.

[21] Bhatt, B., R. Singh, L. Misra, J. Tomar, M. Singh, D. Chauhan, S. Dhyani, K. Singh, K. Dhiman, and M. Datta. 2001. Agroforestry research and practices: An overview. Steps towards modernization of agriculture in NEH region: 365-392.

[22] Shaheen, H., Z. Ullah, S. M. Khan, and D. M. Harper. 2012. Species composition and community structure of western Himalayan moist temperate forests in Kashmir. Forest Ecology and Management 278:138-145.

[23] Sundriyal, R., E. Sharma, L. Rai, and S. Rai. 1994. Tree structure, regeneration and woody biomass removal in a sub-tropical forest of Mamlay watershed in the Sikkim Himalaya. Vegetatio 113 (1):53-63.

[24] Wangchuk, K. 2007. Natural regeneration ecology of mixed conifer forests in Western Bhutan, Vienna University.

[25] Negi, B. S., D. Chauhan, and N. Todaria. 2008. Comparative plant diversity between panchayat and adjoining reserve forests in Garhwal Himalaya. Indian Journal of Forestry 31 (4):585-593.

[26] Storch, I., and I. S. S. Commission. 2007. Grouse: status survey and conservation action plan 2006-2010: IUCN. 
[27] Shaheen, H., R. A. Qureshi, Z. Ullah, and T. Ahmad. 2011. Anthropogenic pressure on the western Himalayan moist temperate forests of Bagh, Azad Jammu \& Kashmir. Pak. J. Bot 43 (1):695-703.

[28] Butt, T. M. 2006. Sustainable forest management: A case study on Machiara national park in district Muzaffarabad, state of Azad Jammu and Kashmir, Pakistan, Department of Geography Norwegian University of science and technology.

[29] Chettri, N., B. Shakya, R. Thapa, and E. Sharma. 2008. Status of a protected area system in the Hindu Kush-Himalayas: An analysis of PA coverage. The International Journal of Biodiversity Science and Management 4 (3):164-178.

[30] Negi, S. P. 2009. Forest cover in Indian Himalayan states-An overview. Indian Journal of Forestry 32 (1):1-5.

[31] Dalling, J. W., and S. Hubbell. 2002. Seed size, growth rate and gap microsite conditions as determinants of recruitment success for pioneer species. Journal of Ecology 90 (3):557-568.

[32] Vallentine, J. F. 2000. Grazing management: Elsevier.

[33] Rehman, E. U. 2007. An Overview of Forest Habitat's Situation in Village Barali Kass, Kotli Azad Kashmir Pakistan. Ethnobotanical Leaflets 2007 (1):30

[34] Wu, R., and H. Tiessen. 2002. Effect of land use on soil degradation in alpine grassland soil, China. Soil Science Society of America Journal 66 (5):1648-1655.

[35] Akhtar, T., and A. Mian. 2009. Phytosociological analysis within the range of grey goral in Pakistan and Azad Kashmir. Pakistan Journal of Botany 41 (2):667-682.
[36] Mayer, R., R. Kaufmann, K. Vorhauser, and B. Erschbamer. 2009. Effects of grazing exclusion on species composition in high-altitude grasslands of the Central Alps. Basic and Applied Ecology 10 (5):447-455.

[37] Rooney, T. P., and D. M. Waller. 1998. Local and regional variation in hemlock seedling establishment in forests of the upper Great Lakes region, USA. Forest Ecology and Management 111 (2):211-224.

[38] Czegledi, L., and A. Radacsi. 2005. Overutilization of pastures by livestock. Acta pascuorum (Grassland studies) 3:29-36.

[39] Kirschbaum, M. U. 2000. Forest growth and species distribution in a changing climate. Tree physiology 20 (5-6):309-322.

[40] Covington, W. W., and M. M. Moore. 1994. Southwestern Ponderosa forest structure. Journal of Forestry 92 (1):39-47.

[41] Cochard, R., and M. Dar. 2014. Mountain farmers' livelihoods and perceptions of forest resource degradation at Machiara National Park, Pakistan-administered Kashmir. Environmental Development 10:84-103.

[42] Qadir, M. A. 1994. Revised Management Plan for the Forests of Muzaffarabad Division (1994-2003). Forest Department, Government of Azad Jammu and Kashmir, Muzaffarabad.

[43] Termizi, S. S. H., and C. M. Rafique. 2001. Forestry Statistics of Azad Kashmir: Forest Department Azad Jammu and Kashmir.

[44] Shahbaz, B. 2009. Dilemmas in Participatory Forest Management in Northwest Pakistan. A Livelihood perspective 25. 